\title{
Peran Gereja Masa Kini Menyikapi Teologi Pembebasan Gutiérrez
}

\author{
Fajar Gumelar*, Hengki Wijaya \\ Sekolah Tinggi Filsafat Jaffray Makassar, Sulawesi Selatan \\ *fajargumelar21298@gmail.com
}

\begin{abstract}
The background of Latin American society in the past who were familiar with the hegemony of power of the bourgeoisie caused concern in the hearts of Christian theologians at the time. This concern finally gave birth to a theological model known as Liberation Theology. Liberation Theology is a praxis oriented theological model, namely real action for the liberation of marginalized, poor and oppressed people. But the thought of Marxism influenced the concept of Liberation Theology so that the theological model was more like a destructive ideology. Bringing the concept of Liberation Theology to the light of the word of God is the right action for the church today in responding to the Liberation Theology. The aim is to analyze the contents of Liberation Theology, and how should the role of the church address the Liberation Theology, and apply liberation theology in everyday life. The method used is an explanatory qualitative approach to the role of the church in response to Liberation Theology.
\end{abstract}

Keywords: church; Gutiérrez; liberation; praxis

\begin{abstract}
Abstrak: Latar belakang masyarakat Amerika Latin di masa lampau yang akrab dengan hegemoni kekuasaan kaum borjuis menyebabkan timbulnya keprihatinan dalam hati para teolog Kristen kala itu. Keprihatinan ini akhirnya melahirkan suatu model teologi yang dikenal dengan nama Teologi Pembebasan. Teologi Pembebasan adalah model teologi yang berorientasi pada praksis, yaitu tindakan nyata untuk pembebasan kaum termarginalkan, miskin dan tertindas. Akan tetapi pemikiran Marxisme turut memengaruhi konsep Teologi Pembebasan sehingga model teologi ini lebih mirip ideologi yang destruktif. Membawa konsep Teologi Pembebasan kepada terang firman Tuhan adalah tindakan yang tepat bagi gereja masa kini dalam menyikapi Teologi Pembebasan. Tujuan tulisan ini adalah menganalisis isi Teologi Pembebasan, dan bagaimana seharusnya peran gereja menyikapi Teologi Pembebasan tersebut, dan menerapkan teologi pembebasan dalam kehidupan sehari-hari. Metode yang digunakan adalah pendekatan kualitatif yang bersifat eksplanatori tentang peran gereja menyikapi Teologi Pembebasan.
\end{abstract}

Kata Kunci: gereja; Gutiérrez; pembebasan; praksis

\begin{tabular}{llll}
\hline Article History : & Received: 02-02-2019 & Revised: 21-03-2019 & Accepted: 29-03-2019
\end{tabular}

\section{Pendahuluan}

Salah satu masalah krusial yang dihadapi oleh masyarakat Indonesia saat ini adalah berkenaan dengan stratifikasi dan diferensiasi sosial, kemiskinan, dan diskriminasi. Di saat sebagian orang hidup dengan segala kemudahan, sebagian lainnya justru menderita dan hidup serba kekurangan. Di saat yang lain dipermudah dalam berbagai layanan 
publik, yang lain justru dipersulit. Belum lagi kentalnya budaya patriarkal yang begitu diskriminatif. Berdasarkan kenyataan bahwa gereja tumbuh dan berkembang dalam konteks sosial masyarakat Indonesia yang demikian, gereja dituntut untuk tidak menutup mata terhadap berbagai isu sosial masyarakat yang terjadi disekitarnya, sebab gereja dipanggil untuk memberitakan kabar baik bagi mereka yang tertindas dan tertawan serta membawa damai sejahtera Allah bagi dunia. Gagasan ini pada dasarnya merupakan bagian dari konsep Teologi Pembebasan yang mula-mula lahir di Amerika Latin, dan kemudian turut memengaruhi Asia termasuk Indonesia, sebagai bentuk keinsafan gereja akan tanggung jawabnya terhadap isu sosial masyarakat di sekitar.

Artikel bertujuan untuk menganalisis isi Teologi Pembebasan, dan bagaimana seharusnya gereja - sebagai saksi Kristus yang hadir ditengah konteks sosial masyarakat Indonesia yang timpang dan diskriminatif - menyikapi Teologi Pembebasan tersebut, dan bagaimana gereja menerapkan teologi pembebasan dalam kehidupan sehari-hari. Sejarah lahirnya Teologi Pembebasan tidaklah lepas dari keadaan Amerika Latin di masa lampau. Orang-orang dari Amerika Utara, yakni orang-orang suku Indian berpindah ke wilayah Amerika Tengah dan Selatan, yang kemudian dikenal sebagai negeri-negeri Amerika Latin. ${ }^{1}$ Suku Indian kemudian menjadi penduduk asli disitu dan sangat mencintai alam dan tanahnya. ${ }^{2}$ Keadaan yang damai dan tenteram itu berubah setelah kedatangan bangsa Eropa khususnya Spanyol dan Portugis pada tahun 1942 dan mulai menguasai dan mengeksploitasi kekayaan alam dan tanah benua itu dan memperlakukan penduduk asli dengan sewenang-wenang. ${ }^{3}$

Keadaan Amerika Latin yang kaya dengan sumber daya alam ternyata tidak menjamin kesejahteraan rakyatnya. Justru rakyat dikepung dengan kemelaratan dikarenakan kekayaan alam hanya dikuasai oleh segelintir orang bermodal yang memperkaya diri dengan menghalalkan segala cara, termasuk mengorbankan kaum lemah. ${ }^{4}$ Keadaan penduduk yang memprihatinkan ini menimbulkan berbagai reaksi, khususnya dari dalam gereja. Konsep pemikiran Teologi Pembebasan yang berorientasi pada praksis muncul dari kalangan para teolog Katolik. Teolog-teolog pembebasan itu antara lain Rigoberta Manchú Tum, Frei Betto, Hugo Assmann dan Gustavo Gutiérrez. ${ }^{5}$

\section{Metode Penelitian}

Penelitian kualitatif instrumen utamanya adalah peneliti sendiri yang mencari sumber terpercaya yang diharapkan dapat melengkapi data yang telah ditemukan melalui

\footnotetext{
${ }^{1}$ Hendri Mulyana Sendjaja, “'Mewartakan Kabar Baik Pembebasan Bersama dan Bagi Yang Miskin, Tertawan dan Tertindas': Menghayati Kembali Kehadiran Teologi Pembebasan Amerika Latin dan Perkembangan Mutakhir Teologi-Teologi Pembebasan Asia" (makalah dipresentasikan pada Konsultasi Nasional Mahasiswa Teologi di Indonesia, STT IKAT, Jakarta, 4 September 2018).

2Ibid.

${ }^{3}$ Ibid.

${ }^{4}$ Stevri I. Lumintang, Theologia Abu-Abu Pluralisme Agama (Malang: Gandum Mas, 2004) 398.

${ }^{5}$ Hendri Mulyana Sendjaja, "Mewartakan Kabar Baik Pembebasan."
} 
observasi, wawancara, dan penelusuran literatur kepustakaan. ${ }^{6}$ Pembahasan di dalam paper dengan pendekatan kualitatif yang bersifat eksplanatori, yang menjelaskan segala hal berkaitan dengan teologi pembebasan dalam hubungannya dengan peran gereja melalui pembahasan teoritik yang sumbernya adalah literatur berupa buku dan jurnal. Penekanan pembahasan di arahkan pada usaha mencari penjelasan makna, dan fenomena berkaitan dengan pokok pembahasan. ${ }^{7}$

\section{Pembahasan}

\section{Gustavo Gutiérrez dan Teologi Pembebasan}

Diantara sekian banyak teolog-teolog pembebasan, Gutiérrez adalah salah satu yang paling tersohor. Gutiérrez lahir pada tanggal 8 Juni 1928 di Monserat, sebuah kawasan di Lima, Peru. ${ }^{8}$ Terlahir dalam keluarga yang relatif miskin tampaknya telah membuat Gutiérrez memiliki rasa empati yang besar terhadap kehidupan orang-orang lain disekitarnya yang memiliki nasib yang sama atau bahkan lebih buruk darinya. Sebagai seorang teolog, Gutiérrez melihat kehidupan kaum termarginalkan, miskin dan tertindas sebagai urgensi atau isu krusial dari sebuah teologi. "Teologi pembebasan dimulai sebagai refleksi iman dalam tindakan bersama atas orang miskin dan yang terpinggirkan, dan telah berkembang ke ranah praksiks, refleksi teologis, dan hermeneutika pascakolonial."9

Gutiérrez berpandangan bahwa teologi seharusnya adalah the second act yang mengikuti praksis yang adalah the first act. ${ }^{10}$ Yang dimaksud dengan praksis adalah kontemplasi (doa) dan aksi (komitmen). Inilah yang mencirikan Teologi Pembebasan, bahwa praksis selalu mendahului refleksi. Teologi Pembebasan pada umumnya memfokuskan praksis pembebasan bagi kaum termargi-nalkan, yang miskin, tertindas dan teraniaya, dengan tidak semata-mata menyuarakan keprihatinan dan kepedulian dari belakang meja belajar, tetapi turut menceburkan diri dalam kehidupan rakyat dan bersama-sama mengupayakan apa yang menjadi tuntutan dan keinginan mereka. ${ }^{11}$

Berdasarkan pengamatan Gutiérrez terhadap konteks sosio-kultural Amerika Latin, kemiskinan Amerika Latin adalah kemiskinan struktural, artinya orang dibuat miskin. ${ }^{12}$

\footnotetext{
${ }^{6}$ Hengki Wijaya, Analisis Data Kualitatif Ilmu Pendidikan Teologi (Makassar: Sekolah Tinggi Filsafat Jaffray Makassar, 2018), 23.

${ }^{7}$ Sonny Eli Zaluchu, Sistematika Riset dan Analisis Data Kuantitatif (Semarang: Golden Gate Publishing, 2018), 22-23.

8Mateus Mali, “Gutiérrez dan Teologi Pembebasan," Orientasi Baru 25, no. 1 (April 2016): 20, diakses 22 Januari 2019, http://e-journal.usd.ac.id/index.php/job/article/viewFile/1099/871.

${ }^{9}$ William T. Cavanaugh, Peter Manley Scott (ed.), Wiley Blackwell Companion to Political Theology (USA: John Wiley \& Son.Ltd, 2019), 302-303. Band: Ivan Sampe Buntu, "Membaca Teks Dalam Pandangan Poskolonial: Catatan Kritis Atas Bacaan Terhadap Teks Kitab Suci," BIA': Jurnal Teologi dan Pendidikan Kristen Kontekstual 1, no. 2 (2018): 179-190.

10Ibid., 20.

${ }^{11}$ Hendri Mulyana Sendjaja, “'Mewartakan Kabar Baik Pembebasan Bersama dan Bagi Yang Miskin, Tertawan dan Tertindas': Menghayati Kembali Kehadiran Teologi Pembebasan Amerika Latin dan Perkembangan Mutakhir Teologi-Teologi Pembebasan Asia"

${ }^{12}$ Mateus Mali, “Gutiérrez dan Teologi Pembebasan," 25.
} 
Kemiskinan struktural merupakan konsekuensi interaksi kelas bawah masyarakat dengan kelas atas yang kapitalis dan berkarajter feodal. Perpaduan antara kapitalisme (eksternal) dan sikap feodal para pemodal (internal) berperanan di dalam memunculkan kemiskinan. ${ }^{13}$ Ada suatu sistem yang secara struktural terbentuk di kalangan para pemilik modal atau kaum kapitalis untuk memperkaya diri sendiri dengan mengorbankan kesejahteraan masyarakat miskin. Sistem ini membuat yang kaya semakin kaya dan yang miskin semakin miskin dan tertindas. Kesenjangan dan ketidakadilan inilah yang coba dibereskan oleh konsep Teologi Pembebasan ala Gutiérrez. Ia ingin mendamaikan materialisme dan idealisme dunia (profan) dengan surga (transenden)."14 Gutiérrez mengatakan bahwa ia membuat tiga penemuan bahwa perlu memerangi kemiskinan, orang miskin adalah kelas yang dapat diidentifikasi, dan bahwa "kemiskinan tidak disengaja...bukan hanya masalah kebetulan, tetapi hasil dari struktur."15

Fenomena kontemporer adalah kemiskinan kolektif yang mengarahkan mereka yang menderita untuk menjalin ikatan solidaritas di antara mereka sendiri dan untuk perjuangan melawan kondisi di mana mereka berada dan melawan mereka yang mendapat manfaat dari kondisi ini. ${ }^{16}$ Dengan kata lain konsep Teologi Pembebasan berusaha untuk menciptakan keharmonisan dalam hidup setiap umat manusia dimana sukacita surga yang mulia dinyatakan di dalam dunia yang fana. Dalam pandangan Teologi Pembebasan, gerejalah yang harus menjadi pemrakarsa dari tindakan ini sebagai saksi Kristus dan warga kerajaan Allah, bukannya sekadar berdiam diri atau malah mendukung hegemoni kekuasaan yang menindas kaum lemah. Satu penekanan penting dalam konsep pembebasan Gutiérrez adalah bahwa "sesuatu yang transenden tidak mungkin dibicarakan atau diwartakan tanpa adanya sebuah perubahan pada tatanan masyarakat yang tidak adil."17

Tiga penemuan Gustavo Gutiérrez mengenai kemiskinan yaitu:18 1 ) kemiskinan adalah destruktif, sesuatu yang saling berlawanan, dan menghancurkan bukan sesuatu yang dapat diterima oleh tindakan kasih; 2) kemiskinan bukan kebetulan tetapi berstruktur. Maka diperlukan suatu perubahan baru; 3) kemiskinan adalah suatu kelas sosial sehingga terjadi diskriminasi dan eksploitasi status. Oleh karena itu Gutiérrez bertindak membantu yang miskin, dan membawa pemikirannya masuk dalam tindakan politik.

\footnotetext{
13Ivanovich Agusta, Diskursus, Kekuasaan dan Praktik Kemiskinan di Pedesaan (Jakarta: Yayasan Pustaka Obor Indonesia, 2014), 137-138.

14Mateus Mali, “Gutiérrez dan Teologi Pembebasan," 25-26.

${ }_{15}$ Paul E. Sigmud, Liberation theology at the crossroads : democracy or revolution? (New York: Oxford University Press, Inc, 1990).

${ }^{16}$ Gustavo Gutiérrez, A Theology Of Liberation History, Politics, And Salvation (Maryknoll, N.Y.: Orbis, 1973), 163-164.

17Mateus Mali, “Gutiérrez dan Teologi Pembebasan,” 26.

${ }_{18}^{18}$ Robert McAfee Brown, Gustavo Gutierrez: An Introduction to Liberation Theology (Eugene, Oregan: Wips and Stock Publisher, 2013), 32.
} 
Teologi Pembebasan memiliki empat metode. Pertama, Teologi Pembebasan bertitik tolak dari situasi Amerika Latin. Teologi haruslah secara intrinsik dihubungkan dengan situasi, budaya, dan sosial yang khusus. ${ }^{19}$ Teologi Pembebasan bukanlah teologi yang bersifat universal tetapi kontekstual. Konteks pembebasan yang diupayakan terhadap masyarakat termarginalkan di Amerika Latin tentu tidak dapat diterapkan dalam konteks masyarakat lain. Hal ini dikarenakan adanya kekhasan sosio-kultural dalam setiap komunitas masyarakat. Untuk itu gereja harus selalu melihat isu krusial dalam masyarakat, dan melihat konsep pembebasan seperti apa yang perlu disuarakan dan diupayakan.

Kedua, teologi sebagai refleksi kritis di dalam komunitas. Menurut Gutiérrez, "teologi haruslah keluar dari kehidupan iman yang berusaha menjadi otentik dan sempurna."20 Keotentikan dan kesempurnaan kekristenan yang sejati itu dapat dicapai apabila gereja memihak kepada masyarakat miskin dan melibatkan diri dalam perjuangan untuk membebaskan mereka. ${ }^{21}$ Gutiérrez memiliki pemikiran kedatangan Kerajaan dan pengharapan parousia adalah selalu dan pasti bersifat historis, temporal, realitas duniawi, sosial dan material. ${ }^{22}$ Dalam bukunya yang berjudul On the side of the poor: the theology of liberation ${ }^{23}$ pemikiran Gutiérrez, dan Müller mengingatkan komunitas gereja, mengapa teologi pembebasan merupakan hadiah penting bagi gereja global. Esai Müller sangat berwawasan luas karena mereka mengklarifikasi aspek-aspek tertentu dari teologi pembebasan (misalnya menjelaskan konteks, dan kontribusinya pada teologi) sambil menawarkan alasan yang meyakinkan tentang mengapa teologi pembebasan harus dipandang lebih dari sekadar teologi regional belaka. Namun Teologi Pembebasan tidak boleh hanya memandang kemiskinan adalah tanggung jawab gereja saja tetapijuga tanggung jawab secara universal. Kemiskinan akan selalu ada di antara kita, namun yang terpenting bagaimana mengimplementasikan iman Kristen sehingga kaum miskin menyadari ada pembebasan yang lebih baik daripada kemiskinan itu sendiri yaitu pembebasan yang diberikan oleh Allah, dan bukan pembebasan yang diusahakan oleh manusia atau pemahaman teologi semata.

Ketiga, menempatkan praksis sebagai peran utama bagi pembebasan kaum tertindas. ${ }^{24}$ Seperti yang sudah disebutkan sebelumnya bahwa praksis merupakan the first act dalam konsep Teologi Pembebasan. Gutiérrez melihat bahwa belas kasihan adalah pusat dari kekristenan, sehingga teologi Kristen haruslah menyangkut praksis yang secara konkret menerapkan kasih itu dalam kehidupan, khususnya dalam kegiatan

\footnotetext{
${ }^{19}$ Natalie, "Evaluasi Kritis Terhadap Doktrin Gereja Dari Teologi Pembebasan," Veritas 1, no. 2 (Oktober 2000): 184.

${ }^{20}$ Ibid., 184.

${ }^{21}$ Ibid.

${ }^{22}$ Tim Gorringe, "Cult books revisited: Gustavo Gutierrez's A Theology of Liberation," Theology 120, no. 4 (2017): 249, https://doi.org/10.1177/0040571X17698408.

${ }^{23}$ Gustavo Gutiérrez and Gerhard Ludwig Müller, On the Side of the Poor: The Theology of Liberation (Maryknoll, New York: Orbis Books, 2015).

${ }^{24}$ Ibid., 185.
} 
pembebasan kaum miskin dan tertindas. "Teologi Pembebasan dalam seluruh tujuan praksisnya menyamakan: mencintai sesama sama dengan mencintai Tuhan."25 Teologi yang dicari oleh Gutierrez adalah sesuatu yang terbuka bagi anugerah Kerajaan Allah dalam protes menentang martabat manusia yang terinjak-injak, perjuangan melawan penjarahan sebagian besar orang, kasih yang membebaskan, dan pembangunan yang baru, adil, dan masyarakat persaudaraan. ${ }^{26}$

Keempat, teologi adalah the second act yang mengikuti praksis. ${ }^{27}$ Dalam tindakan pertama, gereja memainkan perannya sebagai saksi Kristus yang berdiri di pihak orangorang miskin, tertawan dan tertindas. Sementara tindakan kedua adalah refleksi terhadap praksis yang kemudian diajarkan sebagai sebuah teologi.

Dari penjelasan keempat metode tersebut di atas maka metode keempat mengaitkan Teologi Pembebasan dan konsep pemikiran Marxisme. Teologi Pembebasan pada hakikatnya tidaklah lepas dari konsep pemikiran Marxisme. Marxisme adalah paham yang berlandaskan pada pandangan-pandangan Karl Marx. Dalam pandangan Marxisme dikatakan bahwa agama adalah candu masyarakat. ${ }^{28}$ Posisi kekristenan yang mapan dan berpengaruh kala itu akhirnya memunculkan pendekatan materialistik dalam memahami agama. Hal ini kemudian menjadikan agama berkembang menjadi alat justifikasi kelas. ${ }^{29}$ Para penguasa yang dipandang sebagai wakil Tuhan ternyata justru menciptakan sistem yang diskriminatif dan egosentris. Freuerbach turut melihat bahwa terjadi penguasaan agama oleh kaum hegemonik yang kemudian berimplikasi pada pembentukan strata kelas-kelas dalam masyarakat, bahkan pola penindasan dan perilaku subordinatif lainnya oleh kelas penguasa kepada publik. ${ }^{30}$ Agama menjadi candu bagi masyarakat yang membuat ketagihan untuk menjaga survivalitas akan keistimewaan kelas yang didapatkannya. ${ }^{31}$ Namun, keyakinan Kristen bukanlah agama atau legalitas di masyarakat, tetapi pribadi yang menyatakan kasih-Nya atas manusia, dan manusia pun melakukan kasih-Nya kepada yang lainnya.

Teologi Pembebasan tidak dapat dilepaskan dari empat pilar pemikiran Marxisme. Adapun empat pilar Marxisme yang diadopsi oleh Teologi Pembebasan adalah: a) analisis perjuangan kelas; b) mengutuk harta milik/kekayaan pribadi; c) mendukung pemberontakan yang keras; d) "manusia baru" menebus dirinya sendiri (menjadi

${ }^{25}$ Mateus Mali, “Gutiérrez dan Teologi Pembebasan,” 32.

${ }^{26}$ Tim Gorringe, “Cult books revisited: Gustavo Gutierrez’s A Theology of Liberation,” Theology 120, no. 4 (2017): 252, https://doi.org/10.1177/0040571X17698408.

27Natalie, "Evaluasi Kritis Terhadap Doktrin Gereja Dari Teologi Pembebasan,” 186.

${ }^{28}$ Wasito Raharjo Jati, "Agama dan Politik: Teologi Pembebasan Sebagai Arena Profetisasi Agama," Walisongo 22, no. 1 (Mei 2014): 136, diakses 24 Januari 2019,

http://journal.walisongo.ac.id/index.php/walisongo/article/view/262/243.

${ }^{29}$ Wasito Raharjo Jati, "Agama dan Politik: Teologi Pembebasan Sebagai Arena Profetisasi Agama," 136.

${ }^{30}$ Ibid., 137.

31Ibid. 
juruselamat bagi dirinya sendiri). ${ }^{32}$ Teologi Pembebasan pun turut menerapkan sepuluh dasar pemahaman Marxisme terhadap iman Kristen, yang hasilnya adalah: a) tidak mengakui adanya kejatuhan; b) menyangkal bahwa kematian merupakan akibat dari kejatuhan; c) menjadikan Allah sebagai Marxis pertama; d) menjadikan Yesus sebagai pencipta subversi; e) tidak mengindahkan karya penebusan; f) mengubah arti pertobatan (pertobatan ada dalam bentuk pembebasan terhadap orang-orang miskin dan yang tertindas); g) menyimpangkan makna kasih (disebut kasih jikalau terlibat dalam pemberontakan dan perjuangan melawan penindas); h) memindahkan "perbuatan- perbuatan" Kristen ke dalam praksis Marxisme; i) menundukkan gereja kepada mandat Marxis; j) tidak memiliki doktrin eskatologis yang benar. ${ }^{33}$ Pernyataan di atas adalah pertimbangan sebagai kritik yang mana Teologi Pembebasan mengabaikan rencana Allah bagi umat-Nya sekiranya Dia mengizinkan kemiskinan itu ada sebagai konsekuensi rencana-Nya dan kehendak-Nya di masa yang akan datang. Gereja hadir untuk melakukan kehendak-Nya, dan kehendak Allah bukanlah satusatunya untuk memihak kaum miskin, dan terpinggirkan tetapi kehendak Allah yang membebaskan.

Dalam perjalanan sejarah Teologi Pembebasan yang panjang membawa generasi baru para teolog Teologi Pembebasan pada masa kini yang dituliskan secara jelas dalam buku The Future of Liberation Theology: An Argument and Manifesto, ${ }^{34}$ Ivan Petrella menjelaskan bahwa teologi pembebasan saat ini mendapati dirinya tidak mampu bergerak lebih dari sekadar berbicara tentang pembebasan untuk benar-benar diberlakukan dalam masyarakat. Memberikan interpretasi baru yang berani tentang keadaan saat ini, dan potensi masa depan dari teologi pembebasan. Selanjutnya Ivan Petrella menyatukan penelitian orisinal tentang gerakan, dengan perkembangan dalam teori politik, teori hukum kritis, dan politik ekonomi untuk merekonstruksi pemahaman teologi pembebasan tentang teologi, demokrasi dan kapitalisme. Hasilnya adalah pemulihan proyek-proyek sejarah, sehingga memungkinkan para teolog pembebasan untuk sekali lagi menempatkan realitas pembebasan, dan bukan hanya janji, di garis depan tugas mereka. ${ }^{35}$ Dengan demikian semakin nyata perjuangan para teolog Teologi Pembebasan untuk mewujudkan Teologi Pembebasan dalam realitas kehidupan Kristen, dan bergereja.

Pemikiran Gutiérrez yang melahirkan Teologi Pembebasan di masa lalu, dan perbedaannya di masa kini menanggapi relevansi Teologi pembebasan pada masa kini yang man konteks Teologi pembebasan pada masa itu tidak melihat tantangan di masa yang akan datang. Gutiérrez menilai bahwa Teologi pembebasan saat ini telah

${ }^{32}$ Natalie, “Evaluasi Kritis Terhadap Doktrin Gereja Dari Teologi Pembebasan,” 185.

33Ibid., 185. 2017).

${ }^{34}$ Ivan Petrella, The Future of Liberation Theology: An Argument and Manifesto, 1st ed. (Routledge,

35Ibid. 
memasuki periode baru. Gutiérrez juga berpandangan bahwa Teologi tentu membawa tanda waktu, dan konteks eklesial di mana teologi tersebut dilahirkan. Mereka hidup sejauh kondisi yang melahirkan mereka tetap ada. Teologi-teologi yang pernah ada dapat mengatasi berbagai tantangan, namun berjalannya waktu maka teologi tersebut pun akhirnya tunduk dengan waktu yang ada. Kita merujuk, tentu saja, ke mode tertentu dari suatu teologi (rangsangan langsung, instrumen analitis, gagasan filosofis, dan lainlain), bukan fundamental afirmasi tentang kebenaran yang diungkapkan. ${ }^{36}$ Ivan Petrella menyikapi pernyataan Gutiérrez dengan memberikan penilaian atas dirinya.

Bagi Gutiérrez, dalam kasus teologi pembebasan tertentu, kebenaran esensial yang diungkapkan itu berkisar pada apa yang disebut opsi preferensial bagi kaum miskin. Pilihan untuk orang miskin adalah evangelikal secara radikal, dan dengan demikian merupakan kriteria penting untuk memisahkan gandum dari sekam dalam peristiwa mendesak, dan arus pemikiran kita hari ini. Perhatikan bahwa Gutiérrez membedakan kebenaran teologi yang diungkapkan dari sarana yang membawa kebenaran itu. Dengan demikian, ada perbedaan yang harus ditarik antara konten yang diungkapkan teologi pembebasan, dan alat sosioanalitik yang digunakan untuk menjelaskan konten itu. Mendiskreditkan mediasi tertentu tidak menyentuh opsi preferensial bagi orang miskin sebagai inti dari teologi pembebasan. ${ }^{37}$

Dengan demikian perlu melihat konteks Teologi Pembebasan pada masa lalu lalu, dan kepentingan Teologi pembebasan pada masa kini. Oleh karena itu, penulis akan menjabarkan penjelasan peran gereja masa kini dalam menyikapi Teologi Pembebasan dalam konteks kekinian.

\section{Gereja dan Teologi Pembebasan}

\section{Batas-Batas Praksis Pembebasan}

Teologi Pembebasan merupakan konsep teologi yang berorientasi pada praksis yang mengupayakan keadilan, dan kesejahteraan bagi semua. Dalam konsep ini, Yesus yang datang ke dunia membawa kasih, dan keadilan-Nya bagi umat manusia. Berdasarkan poin tersebut teologi pembebasan hadir dalam solidaritas sosial sebagai refleksi kehadiran Kristus. Tujuan praksis pembebasan adalah baik dan mulia. Namun melihat dasar pemikiran Marxisme yang diterapkan terhadap iman Kristen dapat disadari pula bahwa ada banyak hal yang janggal dan menyimpang dari konsep Teologi Pembebasan. Konsep Teologi Pembebasan yang berorientasi pada praksis dengan pengaruh pemikiran Marxisme cenderung salah dalam menafsirkan firman Tuhan yang diangkat sebagai dasar teologinya. Teologi Pembebasan tidak mengeluarkan kebenaran firman Tuhan untuk kemudian diterapkan ke dalam kehidupan dunia yang bermasyarakat, tetapi justru mengambil konteks yang terjadi di dalam masyarakat dan mencocok-

\footnotetext{
36Ibid., 3
}

37Ibid. 
kannya atau mengaitkannya dengan ayat-ayat Alkitab yang dianggap mendukung konteks. ${ }^{38}$ Jika titik tolak teologi salah, maka penguraiannya pun adalah salah. Teologi alkitabiah haruslah bertolak dari Alkitab, bukannya memanipulasi ayat-ayat tertentu agar selaras dengan tindakan.

Pandangan Teologi Pembebasan yang mengizinkan penggunaan kekerasan akan berlawanan dengan pengajaran Yesus yang cinta damai. Dengan demikian perspektif teologi pembebasan mengizinkan gereja untuk mengupayakan segala cara, bahkan kekerasan sekalipun untuk dapat menciptakan masyarakat yang tanpa kelas, dan stratifikasi. Hal itu dapat menyebabkan kehidupan gereja tidak selaras lagi dengan firman Tuhan karena telah menjadi serupa dengan dunia. Gereja tidak lagi menjadi terang dan menerapkan kasih yang sesungguhnya. Oleh karena itu, peran gereja dalam menerapkan nilai-nilai Teologi Pembebasan dengan cara Allah bertindak, dan bukan dengan sekehendak manusia. Sebab Allah menghendaki perdamaian.

Praksis dilihat sebagai satu-satunya jawaban terhadap masalah-masalah sosial, bukannya pribadi dan karya Allah Tritunggal di dalam Alkitab. ${ }^{39}$ Jika gereja menerima konsep Teologi pembebasan tanpa evaluasi kritis terhadapnya, maka gereja akan mengalami kekacauan teologi, dan penyimpangan doktrin dari apa yang dicatat dan diajarkan oleh Alkitab. Penerapan Teologi Pembebasan didasarkan pada eksegesis firman Tuhan, dan bukan pemahaman manusia yang dilegalkan dengan firman Tuhan. Untuk itu sebagai gereja haruslah melihat konsep Teologi Pembebasan secara kritis dan menentukan batas-batas praksis yang benar dari model teologi ini. Peran gereja untuk menyikapi pengaruh Teologi Pembebasan yang positif dan negatif. Pengaruh positif yaitu dimana gereja tidak diam melihat realitas sosial yang tidak adil, dan sejahtera yang terjadi di sekitar kehidupan bermasyarakat. Sementara pengaruh negatif adalah ketika gerakan Teologi Pembebasan ini memaksakan pahamnya untuk menolong yang tertindas sekalipun bertentangan dengan pemerintahan, dan menciptakan situasi masyarakat yang tidak damai.

Bila Teologi Pembebasan berpandangan bahwa realitas sosial yang penuh konflik tidak dapat membuat kita melupakan persyaratan kasih universal yang tidak mengenal batasan kelas sosial, ras, atau gender. Penegasan bahwa pribadi manusia adalah agen nasibnya sendiri dalam sejarah harus dibuat sedemikian rupa sehingga inisiatif seenaknya dari Allah dalam proses penyelamatan - yang merupakan akhir dari evolusi historis umat manusia - dapat dengan jelas terlihat. Sesungguhnya, karunia Allah "yang mengasihi kita lebih dahulu" (1 Yoh. 4:19) membingkai dan memunculkan kemanusiaan sebagai respons bebas terhadap kasih itu. ${ }^{40}$ Dengan kutipan ayat 1 Yohanes 4:19 bahwa Allah mengasihi kita lebih dahulu maka wajib untuk mengasihi saudara kita sesama

38Natalie, “Evaluasi Kritis Terhadap Doktrin Gereja Dari Teologi Pembebasa, 190.

39 Ibid.

${ }^{40}$ Gustavo Gutiérrez and Gerhard Ludwig Müller, On the Side of the Poor: The Theology of Liberation (Maryknoll, New York: Orbis Books, 2015). 
manusia. Namun kasih Allah adalah inisiatif Allah bukan perbuatan kasih menusia terhadap sesamanya. Bila manusia mengupayakan kasihnya dengan kekuatannya maka kasih Allah bisa menjadi sama dengan kasih manusia. Hal positifnya bahwa pandangan Teologi Pembebasan memberikan kebebasan untuk menyatakan kasih kepada semua manusia tanpa melihat perbedaan. Dalam gereja masa kini mungkin sulit menyatakan kasih seperti itu bila tidak ada kasih Allah yang telah mengasihi gereja lebih dahulu. Hal yang lain adalah mengapa kaum borjuis dan kaum miskin menunjukkan gap yang luas dan memberikan perbedaan yang nyata dalam agama sebagai legalitas dan gereja sebagai organisasi, maupun organisme. Inilah yang membuat keterkaitan kuat paham Marxisme dan Teologi Pembebasan.

Marxisme dan Teologi Pembebasan pada dasarnya sama-sama mengutuk agama yang melanggengkan status quo dan yang membenarkan kekuasaan kaum borjuis yang diskriminatif. ${ }^{41}$ Teologi Pembebasan juga menyuarakan kritik tegas terhadap kehidupan gereja di masa lampau yang memihak kepada kaum borjuis atau kapitalis yang menindas kaum miskin. ${ }^{42}$ Konteks gereja di Indonesia bisa diupayakan dalam konteks berkeadilan sosial bagi seluruh warga gereja dan sesama manusia sebagai warga negara Indonesia. Gereja tidak hanya menjadi organisasi, namun organisme yang menyuarakan pembebasan Kristus atas dosa, kutuk, dan kasih kepada sesama yang didasarkan pada kasih Allah yang hidup dalam orang percaya, dan gereja-Nya.

Kemunculan Teologi Pembebasan membawa perubahan gereja yang diinsafkan bahwa keadaan hidup bergereja bukan semata-mata sebuah hierarki tetapi umat Allah. Gereja tidak diutus ke dalam dunia untuk memusingkan soal-soal stratifikasi dalam gereja dan masyarakat atau mempertahankan survivalitas akan keistimewaan kelas yang duniawi, tetapi menjadi terang bagi dunia yang gelap. Hal penting lainnya adalah bahwa Teologi Pembebasan memberitakan panggilan kepada gereja untuk menyatakan kasih kepada sesama sebagai wujud dari teologi yang berdasarkan firman Tuhan. ${ }^{43}$ Gereja diingatkan untuk tidak sekadar berfokus kepada pembangunan gedung gereja atau disibukkan dengan hal-hal internal gereja, tetapi melakukan hal yang lebih utama yaitu menjadi saksi Kristus bagi masyarakat di sekitarnya.

Hal-hal ini merupakan sumbangsih positif dari Teologi Pembebasan kepada kehidupan bergereja dan bermasyarakat. Untuk itu gereja perlu untuk memahami bahwa Teologi Pembebasan haruslah digunakan atau diterapkan dengan kacamata Alkitab, bukan pemikiran Marxisme. Artinya adalah bahwa batas-batas praksis Teologi Pembebasan ditentukan oleh apa yang dilarang, dan diamanatkan Allah melalui firman-Nya. Segala konsep yang bertentangan dengan firman Allah harus dibuang, sementara praksispraksis atau pemikiran-pemikiran yang selaras dengan firman Allah haruslah

${ }^{41}$ Mateus Mali, "Gutiérrez dan Teologi Pembebasan," 31.

${ }^{42}$ Natalie, “Evaluasi Kritis Terhadap Doktrin Gereja Dari Teologi Pembebasan," 190.

43Ibid., 190. 
diterapkan dalam kehidupan bergereja, dan bermasyarakat sebagai warga negara Indonesia.

\section{Kristus Sebagai Teladan Gereja dan Pembebasan-Nya}

Teladan sempurna bagi gereja dalam menapaki perjalanan hidup di dunia adalah Yesus Kristus. Kristus sebagai teladan adalah bahwa gereja harus menjadi serupa dengan Kristus. Keteladan Kristus mencakup segala hal yang baik dan seturut kehendak Allah, tidak terkecuali dalam kaitan dengan konsep Teologi Pembebasan. Dalam inkarnasi-Nya sebagai manusia, Yesus memilih untuk lahir dari keluarga sederhana, dari kaum yang terkecil diantara kaum-kaum Yehuda. Bahkan kelahiran-Nya bukanlah di istana atau rumah yang megah, tetapi justru di kandang domba.

Meninjau pada perjalanan kehidupan Yesus ketika hidup sebagai manusia di dunia, dapat pula dilihat bahwa Yesus turut menerapkan praksis pembebasan. Dalam kehidupan pelayanan-Nya, Dia senantiasa memperhatikan kehidupan orang-orang termarjinalkan, miskin dan tertindas. Ia menyembuhkan orang sakit serta memberi makan orang yang kelaparan. Yesus menyatakan keadilan dan kasih Allah bagi dunia secara konkret (Lih. Luk. 4:18-19). Yesus tidak semata-mata menjanjikan keselamatan surgawi tetapi juga berkarya untuk membebaskan manusia dari belenggu penderitaan di dunia, yang antara lain disebabkan oleh kemiskinan; dengan demikian Yesus menjadi pembebas bagi kaum miskin yang tertindas. ${ }^{44}$ Namun yang harus diingat adalah bahwa pelayanan kasih yang dilakukan Yesus tersebut tidaklah menggantikan pemasyhuran Injil. Pelayanan kasih tersebut justru menyertai pemasyhuran Injil.

Dalam Matius 14:13-21 dapat dilihat bahwa Yesus tidak hanya peduli dengan kebutuhan rohani orang banyak, tetapi juga kebutuhan jasmani mereka. Selain memberitakan firman Yesus juga memberi mereka makan ketika mereka lapar. Lebih dari lima ribu orang dikenyangkan oleh makanan rohani maupun makanan jasmani dari Yesus. "Pemasyhuran Injil harus dilakukan dengan pelayanan firman dan pelayanan kasih, dengan firman dan perbuatan." 45 Terkait hal tersebut kehadiran Yesus di dunia ini menghadirkan keduanya sekaligus yaitu pemasyhuran Injil dan kasih-Nya. Gereja hadir untuk menyatakan keselamatan roh oleh Injil, dan keselamatan jasmani oleh perbuatan baik orang percaya melalui komunitas gereja.

Praksis Teologi Pembebasan seharusnya menjadi bagian dari hidup bergereja. Praksis pembebasan itu berorientasi pada keteladanan pembebasan yang dilakukan oleh Yesus. Peran gereja berfokus pada pembebasan Yesus atas belenggu dosa, dan dampaknya mengasihi Allah, dan mengasihi manusia. Gereja harus peka terhadap isuisu atau gejala-gejala sosial di sekitarnya. Gereja harus menjadi garam dan terang bagi dunia. Juga bahwa praksis-praksis pembebasan - berupa kontribusi gereja untuk

\footnotetext{
${ }^{44}$ Bobby Steven Timmerman, "Menghadirkan Yesus Kristus Yang Membebaskan "Para Petani Miskin Yang Tersalib" Di Paroki Mara Satu," Orientasi Baru 23, no. 1 (April 2014): 22, diakses 25 Januari 2019, http://e-journal.usd.ac.id/index.php/job/article/view/1136/900.

${ }^{45}$ Harun Hadiwijono, Iman Kristen (Jakarta: BPK Gunung Mulia, 2016), 387.
} 
menolong orang-orang miskin, tertawan dan tertindas - tidaklah boleh mengabaikan pemashuran Injil. Gereja tidak boleh melupakan tugas panggilannya untuk memberitakan berita Injil bagi dunia. Gereja juga harus menginsafi bahwa segala kontribusinya dalam masyarakat bukanlah supaya mendapat pengakuan dari dunia, melainkan semata-mata supaya Allah dimuliakan, seperti halnya yang Yesus lakukan. Chris Houson mengungkapkan bahwa kehadiran Teologi Pembebasan untuk mengkritik keadaan gereja dengan pertanyaan, dan menantang cara pandang gereja dalam menyikapi relasi gereja dengan sekitarnya. ${ }^{46}$

Gereja hadir di muka bumi untuk menjadi saksi Kristus. Gereja tidak hadir untuk memberi beban, namun berbelas kasihan akan dunia melalui kasih Kristus. Hengki Wijaya dalam tulisannya Analisis Biblika Terhadap Konsep Teologi Pembebasan di dalam Kekristenan menyimpulkan bahwa "Teologi Pembebasan mengingatkan kita untuk menerapkan kebenaran firman Tuhan di dalam tindakan yang nyata. Tidak hanya teori tetapi harus menyatakan perwujudan iman kepada Kristus di dalam tindakan kasih kepada sesama sehingga Kristus dipermuliakan (Mat. 5:13-16;Yak. 2:14- 26)."47 Selanjutnya sikap orang-orang Kristen seharusnya juga tidak hanya dapat memberikan khotbah kepada orang-orang yang tertindas dan dalam kesusahan, namun juga harus mengulurkan tangan kasih sebagai perwujudan yang nyata dari firman yang diberitakan.

\section{Kesimpulan}

Teologi Pembebasan senantiasa berorientasi pada praksis pembebasan kepada kaum termarginalkan, miskin dan tertindas. Namun demikian pemikiran Marxisme turut memengaruhi konsep Teologi Pembebasan. Hal ini tentu bukan suatu hal yang baik. Apalagi oleh pemikiran Marxsis tersebut Teologi Pembebasan menjadi tidak ubahnya seperti ideologi komunis bahkan radikalis yang sama sekali tidak sesuai dengan firman Tuhan. Teologi Pembebasan sejatinya baik untuk diterima dan diterapkan oleh gereja. Untuk itu Teologi Pembebasan harus ditundukkan pada terang Alkitab, sehingga tidak lagi terpengaruh oleh pemikiran Marxisme yang bertentangan dengan Alkitab tetapi Teologi Pembebasan menjadi seruan positif yang menginsafkan gereja untuk tidak sibuk dengan urusan diri sendiri tetapi senantiasa menyatakan kasih Kristus di tengah-tengah hidup bermasyarakat. Peran gereja menyikapi Teologi Pembebasan bukan berdasarkan konteks sejarah lahirnya teologi ini di masa lalu, melainkan nilai-nilai akitabiah yang diterapkan, dan dimplikasikan secara praktis di dalam gereja, dan masyarakat melalui kasih Allah yang membebaskan, dan menciptakan keadilan sosial bagi seluruh rakyat Indonesia.

\footnotetext{
${ }^{46}$ Chris Howson, A Just Church: 21st century Liberation Theology in Action (NY: Continuum International Publishing Group, 2011), $\mathrm{x}$.

${ }^{47}$ Hengki Wijaya, "Analisis Biblika Terhadap Konsep Teologi Pembebasan Di Dalam Kekristenan," diakses 2 Februari 2019, https://repository.sttjaffray.ac.id/publications/269022/analisis-biblikaterhadap-konsep-teologi-pembebasan-di-dalam-kekristenan
} 


\section{Referensi}

Agusta, Ivanovich. Diskursus, Kekuasaan dan Praktik Kemiskinan di Pedesaan Jakarta: Yayasan Pustaka Obor Indonesia, 2014.

Brown, Robert McAfee. Gustavo Gutierrez: An Introduction to Liberation Theology. Eugene, Oregan: Wips and Stock Publisher, 2013.

Buntu, Ivan Sampe. "Membaca Teks Dalam Pandangan Poskolonial: Catatan Kritis Atas Bacaan Terhadap Teks Kitab Suci." BIA': Jurnal Teologi dan Pendidikan Kristen Kontekstual 1, no. 2 (2018): 179-190.

Cavanaugh, William T., Peter Manley Scott (ed.). Wiley Blackwell Companion to Political Theology. USA: John Wiley \& Son.Ltd, 2019.

Gorringe, Tim. "Cult books revisited: Gustavo Gutierrez's A Theology of Liberation." Theology 120, no. 4 (2017): 246-252. https://doi.org/10.1177/0040571X17698408.

Gutiérrez, Gustavo. A Theology Of Liberation History, Politics, And Salvation. Maryknoll, N.Y.: Orbis, 1973.

Gutiérrez, Gustavo, and Gerhard Ludwig Müller. On the Side of the Poor: The Theology of Liberation. Maryknoll, New York: Orbis Books, 2015.

Hadiwijono, Harun. Iman Kristen. Jakarta: BPK Gunung Mulia, 2016.

Jati, Wasito Raharjo. "Agama dan Politik: Teologi Pembebasan Sebagai Arena Profetisasi Agama.” Walisongo 22, no. 1 (Mei 2014): 133-156. Diakses $24 \quad$ Januari 2019.

http://journal.walisongo.ac.id/index.php/walisongo/article/view/262/243.

Lumintang, Stevri I. Theologia Abu-Abu Pluralisme Agama. Malang: Gandum Mas, 2004.

Mali, Mateus. "Gutiérrez dan Teologi Pembebasan.” Orientasi Baru 25, no. 1 (April 2016): 19-36. Diakses 22 Januari 2019.

http://e-journal.usd.ac.id/index.php/job/article/viewFile/1099/871.

Howson, Chris. A Just Church: 21 st century Liberation Theology in Action (NY: Continuum International Publishing Group, 2011.

Natalie. "Evaluasi Kritis Terhadap Doktrin Gereja Dari Teologi Pembebasan." Veritas 1, no. 2 (Oktober 2000): 181-191.

Petrella, Ivan. The Future of Liberation Theology: An Argument and Manifesto. 1st ed. Routledge, 2017. Accessed March 29, 2019. https://www.taylorfrancis.com/books/9781315239460.

Sendjaja, Hendri Mulyana. "Mewartakan Kabar Baik Pembebasan Bersama dan Bagi Yang Miskin, Tertawan dan Tertindas': Menghayati Kembali Kehadiran Teologi Pembebasan Amerika Latin dan Perkembangan Mutakhir Teologi-Teologi Pembebasan Asia." Konsultasi Nasional Mahasiswa Teologi di Indonesia, Jakarta: STT IKAT, 2018.

Sigmud, Paul E. Liberation theology at the crossroads : democracy or revolution? New York: Oxford University Press, Inc, 1990.

Timmerman, Bobby Steven. "Menghadirkan Yesus Kristus Yang Membebaskan "Para Petani Miskin Yang Tersalib” Di Paroki Mara Satu." Orientasi Baru 23, no. 1 (April 2014): 17-29. Diakses 25 Januari 2019.

http://e-journal.usd.ac.id/index.php/job/article/view/1136/900.

Wijaya, Hengki. "Analisis Biblika Terhadap Konsep Teologi Pembebasan Di Dalam Kekristenan.” Diakses 2 Februari 2019. https://repository.sttjaffray.ac.id/publications/269022/analisis-biblika-terhadapkonsep-teologi-pembebasan-di-dalam-kekristenan.

Wijaya, Hengki. Analisis Data Kualitatif Ilmu Pendidikan Teologi. Makassar: Sekolah Tinggi Theologia Jaffray, 2018.

Zaluchu, Sonny Eli. Sistematika Riset dan Analisis Data Kuantitatif. Semarang: Golden Gate Publishing, 2018. 